\title{
AN APPLICATION OF THE MODIFIED FINITE ELEMENT TRANSFER MATRIX METHOD FOR A HEAT TRANSFER PROBLEM
}

\author{
Kanat Burak BOZDOĞAN ${ }^{* 1}$, Farshid KHOSRAVI MALEKI ${ }^{2}$ \\ ${ }^{*}$ Çanakkale Onsekiz Mart University, Engineering Faculty, Civil Engineering Department, Çanakkale. \\ ${ }^{2}$ Bartin University, Engineering Faculty, Mechanical Engineering Department, Bartın.
}

\begin{abstract}
The Transfer Matrix Method is an effective method which is used in mechanics and provides a great advantage especially in solving some mechanical problems. The most important advantage of the Transfer Matrix Method is reducing the dimensions of the matrix used in the analysis. The most important consequence of this is the saving the time.

In this study, firstly studies in recent years in relation with the Transfer Matrix Method have been briefly summarized. Then the Modified Finite Element Transfer Matrix Method is explained briefly. At the end of the study, the application of the Modified Finite Element Transfer Matrix Method to the heat transfer problem has been demonstrated.
\end{abstract}

Key Words: Modified Finite Element Transfer Matrix Method, Mechanics, Heat Transfer Problem

*corresponding author: kbbozdogan@comu.edu.tr 


\section{DEĞISTTIIRILMIŞ SONLU ELEMANLAR TAŞIMA MATRİSi YÖNTEMININ ISI TRANSFERİ PROBLEMINE UYGULANMASI}

\section{Özet}

Taşıma matrisi Yöntemi, mekanikte kullanılan ve özellikle bazı mekanik problemlerin çözümünde büyük avantaj sağlayan etkili bir yöntemdir. Taşıma matrisi yönteminin en önemli avantajı analizde kullanılan matrisin boyutlarını azaltmasıdır. Bunun en önemli sonucu ise zaman dan tasarruftur. Bu çalışmada ilk olarak Taşıma matrisi yöntemi ile ilgili son yıllarda yapılan çalışmalar kısaca özetlenmiştir. Daha sonra Değiştirilmiş Sonlu Elemanlar Taşıma matrisi yöntemi kısaca açıklanmıştır. Çalışmanın sonunda, Değiştirilmiş Sonlu Elemanlar Taşıma matrisi yönteminin 1s1 transfer problemine uygulanması gösterilmiştir.

Anahtar Kelimeler: Değiş̧tirilmiş Sonlu Elemanlar Taşıma Matrisi Yöntemi, Mekanik, Isı Transferi Problemi 


\section{INTRODUCTION}

The transfer Matrix Method is an effective method which is used in mechanics. Firstly, Transfer Matrix Method (TMM) was developed by Holzer (1921) for torsion vibrations of rods [1]. Myklestad (1945) applied TMM for bending -torsion vibrations of beams [2]. Thomson used TMM for the analysis of non- uniform beams [3].

Thompson (1950) and Haskel (1953) applied TMM for the wave propagation analysis in elastic media [4-5]. Pestel and Leckie (1963) applied the TMM method in various elastomechanics problems [6]. Inan (1968) wrote a book which introduce a Carry Over Matrix Method (TMM) [7]. Hoerner (1975) suggested Ricatti Transfer Matrix Method for elimination of the classical TMM errors (propagation and round- off errors) [8].

In cases where the Transfer Matrix cannot be obtained directly, the Transfer Matrix can be obtained by means of the Finite Element Matrix.

There is a series of studies in the literature about Combined Finite Element-Transfer Matrix Method [9-18]. Fan and Barber (2002) used the tranfer matrix method for the periodic heating problems [19].Choi (2003) developed Finite Element-Transfer Stiffness Coefficient method for plate analysis [20]. Rui, Wang, and Lu (2008) adapted the TMM for multibody system analysis [21].

Rong, Rui, and Wang (2011) suggested Modified Finite Element-Transfer Matrix Method [22].

He, Rui and Zhang (2012) applied Transfer Matrix Method for natural vibration analysis for tree systems [23].Ozturk, Bozdogan, and Nuhoğlu (2012) applied Modified Finite Element-Transfer Matrix Method for Static analysis of systems [24]. Ozturk and Bozdogan (2017) proposed A Modidfied Finite element Transfer matrix method for determination of the Fundemantal perios of layered soil profiles [25].Demirkan and Artan applied the transfer matrix method to the stability analysis of Nanobeams based on nonlocal timoshenko beam model [26].

$\mathrm{Xu}$ and Jiang (2019) used the transfer matrix method for the free vibration analysis of retaining wall [27]. Kang et al. (2019) Based on the transfer matrix method, they suggested modeling for periodic graphene structures [28].

In this paper, firstly, Transfer Matrix Method is explained briefly than the application of the Modified Finite element transfer matrix Method to the heat transfer problem has been demonstrated. 


\section{Material and Method}

\subsection{TRANSFER MATRIX METHOD}

The main idea of the TMM is to convert the boundary problem to the initial value problem (Figure 1).

In the TMM, the all unknowns can be written by the means of initial values.

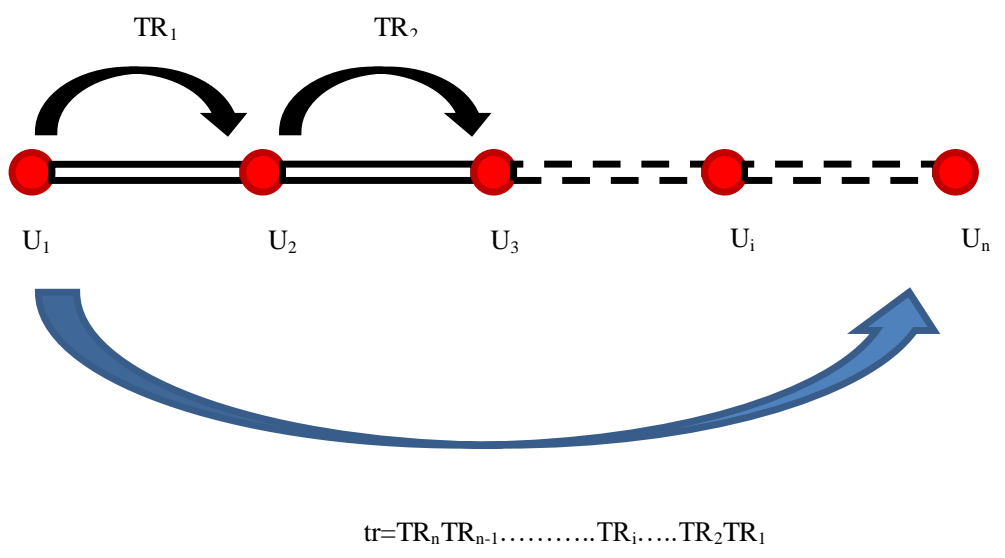

Figure 1. Transfer matrix sheme

The method has some advantages over the finite element method:

1. The size of the system matrix in the TMM is smaller than the conventional Finite Element Method.

2. Provides a fast and practical solution.

3. In TMM, the size of the system matrix is independent of the number of elements The matrix size advantage of the TMM is shown in Figure 2 in comparison with the conventional Finite Element Method. In the given system (Figure 2), there is only one unknown at each node.

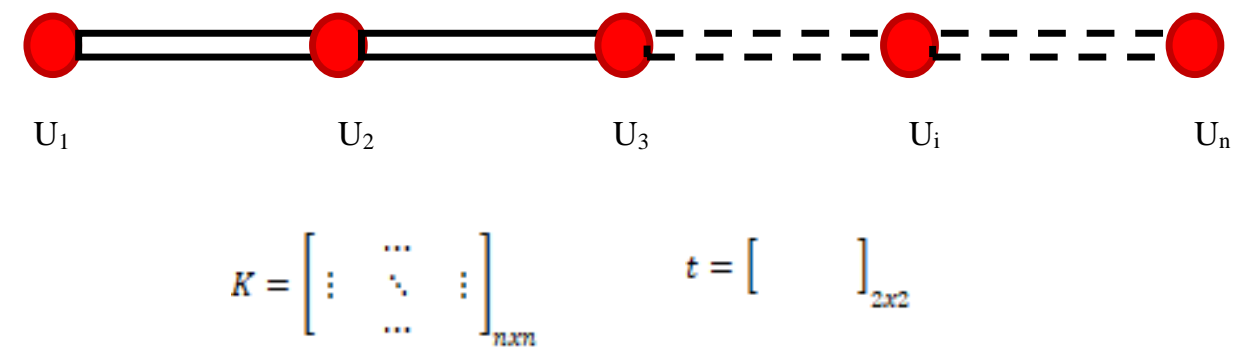

Figure 2. Comparison of system matrix dimension of Finite Element and Transfer Matrix Method. 


\subsection{ORDINARY FINITE ELEMENT-TRANSFER MATRIX METHOD}

In cases where the Transfer Matrix cannot be obtained directly, the Transfer Matrix can be obtained by the help of the finite element matrix [22].

The finite element matrix for element $i$ can be written as

$$
\left[\begin{array}{ll}
k_{11} & k_{12} \\
k_{21} & k_{22}
\end{array}\right]\left\{\begin{array}{c}
U_{i-1} \\
U_{i}
\end{array}\right\}=\left\{\begin{array}{c}
-Q_{i-1} \\
Q_{i}
\end{array}\right\}
$$

where $k_{11}, k_{12}, k_{21}, k_{22}$ are the submatrices of element matrix.

For i.th element, Transfer Matrix is written as

$$
\left[\begin{array}{ll}
T R_{11} & T R_{12} \\
T R_{21} & T R_{22}
\end{array}\right]\left\{\begin{array}{c}
U_{i-1} \\
Q_{i-1}
\end{array}\right\}=\left\{\begin{array}{c}
-U_{i} \\
Q_{i}
\end{array}\right\}
$$

where $T R_{11}, T R_{12}, T R_{21}, T R_{22}$ are the submatrices of element Transfer Matrix.

By using equations (1) and (2), equations (3), (4), (5) and (6) can be written.

$$
\begin{gathered}
T R_{11}=-k_{12}^{-1} k_{11} \\
T R_{12}=-k_{12}^{-1} \\
T R_{21}=k_{21}-k_{22} k_{12}^{-1} k_{11} \\
T R_{22}=-k_{22} k_{12}^{-1}
\end{gathered}
$$

\subsection{MODIFIED FINITE ELEMENT-TRANSFER MATRIX METHOD}

Modified Finite Element-Transfer Matrix (MFETM) method was first developed in 2011 by Rong, Rui and Wang [22].

Using the MFETM , the size of the matrix used in the conventional TMM is reduced by half.

The method is briefly summarized below.

The main idea of the method is to use the following transformations.

$$
\begin{aligned}
& Q_{i-1}=S_{i-1} U_{i-1} \\
& Q_{i}=S_{i} U_{i}
\end{aligned}
$$

If the transformations given in equation (7) and equation (8) are written in equation (1) and if the necessary arrangements are made, equation (9) is obtained.

$$
S_{i}=-k_{21} k_{12} /\left(k_{11}+S_{i-1}\right)+k_{22}
$$


The equation (9) is the main equation of the Modified Finite-Element Transfer Matrix Method.

\subsection{HEAT TRANSFER IN COMPOSITE WALL}

In a composite wall in case of heat transfer the governing differential equation can be written as [29].

$$
k \frac{d^{2} T}{d x^{2}}=0
$$

where $k$ is the thermal conductivity of the material and $T$ is the temperature.

The boundary conditions of equation (10) are given as follows:

$$
\begin{gathered}
T(0)=T_{0} \\
x=x_{\text {end }} \quad k \frac{d T}{d x}+\beta\left(T-T_{\infty}\right)=0
\end{gathered}
$$

where $\beta$ is a film coefficient and $T_{\infty}$ is air temperature.

\subsection{ELEMENT TRANSFER MATRIX FOR HEAT TRANSFER PROBLEM}

The solution of the second order homogenous differential equation is given below:

$$
T(x)=c_{1}+c_{2} x
$$

The heat is calculated by the following equation.

$$
k A \frac{d T}{d x}=k c_{2}
$$

In the starting position the equations (13) and (14) can be written as

$$
\begin{array}{ll}
x=0 & T(0)=c_{1} \\
x=0 & \frac{d T}{d x}=k c_{2}
\end{array}
$$

Equations (15) and (16) can be written in matrix form as

$$
\left\{\begin{array}{l}
T(0) \\
Q(0)
\end{array}\right\}=\left[\begin{array}{cc}
1 & 0 \\
0 & k A
\end{array}\right]\left\{\begin{array}{l}
c_{1} \\
c_{2}
\end{array}\right\}=A\left\{\begin{array}{l}
c_{1} \\
c_{2}
\end{array}\right\}
$$

Equations (13) and (14) can be written at the end of the element as

$$
\begin{gathered}
x=h \quad T(h)=c_{1}+c_{2} h \\
x=h \quad \frac{d T}{d x}=k A c_{2}
\end{gathered}
$$


Equations (18) and (19) can be written in matrix form as

$$
\left\{\begin{array}{l}
T(h) \\
Q(h)
\end{array}\right\}=\left[\begin{array}{cc}
1 & h \\
0 & k A
\end{array}\right]\left\{\begin{array}{l}
c_{1} \\
c_{2}
\end{array}\right\}=B\left\{\begin{array}{l}
c_{1} \\
c_{2}
\end{array}\right\}
$$

Using matrix equations (17) and (20) can be obtained matrix equation (21).

$$
\left\{\begin{array}{l}
T(h) \\
Q(h)
\end{array}\right\}=B^{*} A^{-1}\left\{\begin{array}{l}
T(0) \\
Q(0)
\end{array}\right\}=T R\left\{\begin{array}{l}
T(0) \\
Q(0)
\end{array}\right\}
$$

where $T R$ is the element Transfer Matrix and is calculated by the following matrix.

$$
T R_{i}=\left[\begin{array}{cc}
1 & \frac{h_{i}}{k_{i} A_{i}} \\
0 & 1
\end{array}\right]
$$

\subsection{MODIFIED FINITE ELEMENT TRANSFER MATRIX METHOD FOR HEAT TRANSFER PROBLEM}

For i.th element the finite element matrix for the composite wall is written as

$$
\frac{k_{1} A_{i}}{h_{i}}\left[\begin{array}{cc}
1 & -1 \\
-1 & 1
\end{array}\right]\left\{\begin{array}{c}
T_{i-1} \\
T_{i}
\end{array}\right\}=\left\{\begin{array}{c}
-Q_{i-1} \\
Q_{i}
\end{array}\right\}
$$

In equation (23), the following transformations can be applied in accordance with the MFETM.

$$
\begin{array}{r}
Q_{i-1}=S_{i-1} T_{i-1}+P_{i-1} \\
Q_{i}=S_{i} T_{i}+P_{i}
\end{array}
$$

Using equations (24) and (25), equations (26) and (27) are obtained.

$$
\begin{array}{r}
S_{i}=-\frac{\left(k_{i}^{2} A_{i}^{2} / h_{i}^{2}\right)}{\left(\frac{k_{1} A_{i}}{h_{i}}+S_{i-1}\right)}+\frac{k_{1} A_{i}}{h_{i}} \\
P_{i}=\frac{\frac{k_{1} A_{i}}{h_{i}} P_{i-1}}{\left(\frac{k_{1} A_{i}}{h_{i}}+S_{i-1}\right)}
\end{array}
$$


DOI:10.34186/klujes.564004

\subsection{NUMERICAL EXAMPLE}

In the composite wall shown in the Figure 3. [30], the temperatures at the nodes are calculated.

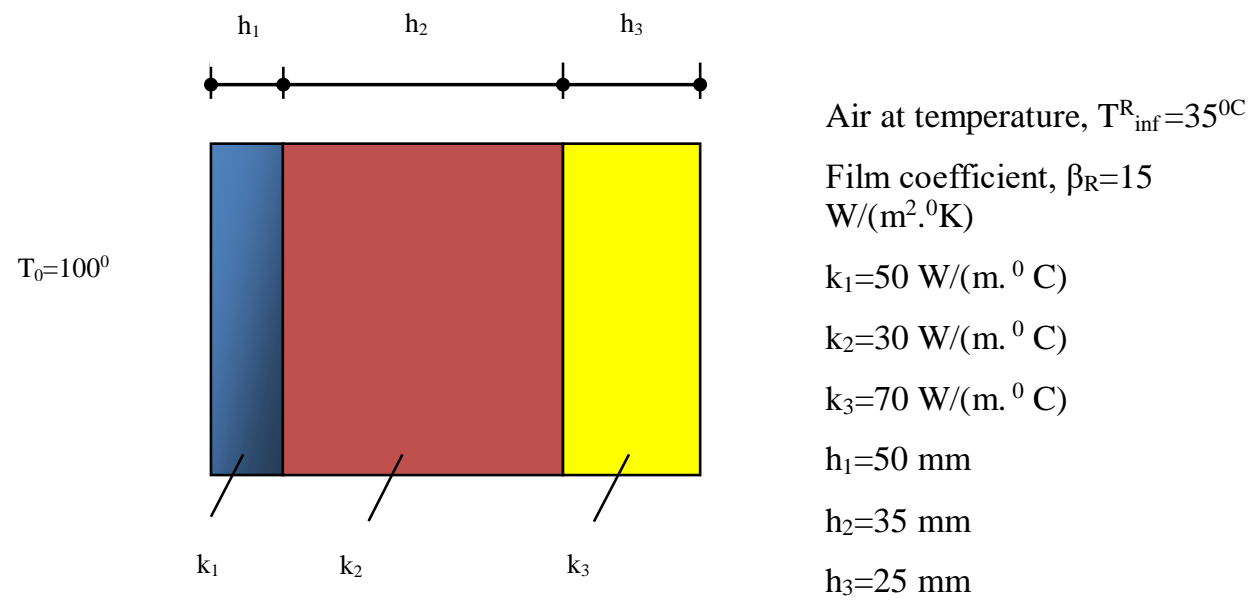

Figure 3. A composite wall

\section{RESULTS AND DISCUSSION}

\subsection{SOLUTION USING THE TRANSFER MATRIX METHOD}

By using equation (22), element transfer matrices for each element are calculated as follows, respectively:

$$
T R_{1}=\left[\begin{array}{cc}
1 & 0.1 \\
0 & 1
\end{array}\right] \quad T R_{2}=\left[\begin{array}{cc}
1 & 0.1167 \\
0 & 1
\end{array}\right] \quad T R_{1}=\left[\begin{array}{cc}
1 & 0.0357 \\
0 & 1
\end{array}\right]
$$

The system transfer matrix is calculated by multiplying the element transfer matrices as follows:

$$
t r=T R_{3} * T R_{2} * T R_{1}=\left[\begin{array}{cc}
1 & 0.25247 \\
0 & 1
\end{array}\right]
$$

In this case, the solution equation is written as follows:

$$
\left\{\begin{array}{l}
T_{4} \\
Q_{4}
\end{array}\right\}=\operatorname{tr}\left\{\begin{array}{l}
T_{1} \\
Q_{1}
\end{array}\right\}
$$

If boundary conditions are applied in this equation, $T_{4}$ and $Q_{1}$ are obtained as follows:

$$
\begin{aligned}
& \left\{\begin{array}{c}
T_{4} \\
525-15 T_{4}
\end{array}\right\}=\left[\begin{array}{cc}
1 & 0.25247 \\
0 & 1
\end{array}\right]\left\{\begin{array}{c}
100 \\
Q_{1}
\end{array}\right\} \\
& T_{4}=48.58^{\circ} \mathrm{C} \quad Q_{1}=-203.66 \mathrm{~W}
\end{aligned}
$$


The other unknowns can be calculated as follows using element transfer matrices and $Q_{1}$.

$$
\begin{array}{r}
\left\{\begin{array}{l}
T_{2} \\
Q_{2}
\end{array}\right\}=T R_{1}\left\{\begin{array}{l}
T_{1} \\
Q_{1}
\end{array}\right\} \\
T_{2}=79.634^{\circ} \mathrm{C} \quad Q_{2}=-203.66 \mathrm{~W} \\
\left\{\begin{array}{l}
T_{3} \\
Q_{3}
\end{array}\right\}=\operatorname{tr}\left\{\begin{array}{l}
T_{2} \\
Q_{2}
\end{array}\right\} \\
T_{3}=55.866^{\circ} \mathrm{C} \quad Q_{3}=-203.66 \mathrm{~W}
\end{array}
$$

\subsection{SOLUTION USING THE MODIFIED FINITE ELEMENT -TRANSFER MATRIX METHOD}

Using the equations (23), (26) and (27), the following expressions can be written.

$$
\begin{gathered}
{\left[\begin{array}{cc}
10 & -10 \\
-10 & 10
\end{array}\right]\left\{\begin{array}{c}
100 \\
T_{2}
\end{array}\right\}=\left\{\begin{array}{c}
-Q_{1} \\
Q_{2}
\end{array}\right\}} \\
S_{2}=10 \\
P_{2}=-k_{21} 100=-1000 \\
{\left[\begin{array}{cc}
8.5714 & -8.5714 \\
-8.5714 & 8.5714
\end{array}\right]\left\{\begin{array}{c}
T_{2} \\
T_{3}
\end{array}\right\}=\left\{\begin{array}{c}
-Q_{2} \\
Q_{3}
\end{array}\right\}} \\
S_{3}=4.6154 \quad P_{3}=-461.385 \\
{\left[\begin{array}{cc}
28 & -28 \\
-28 & 28
\end{array}\right]\left\{\begin{array}{l}
T_{3} \\
T_{4}
\end{array}\right\}=\left\{\begin{array}{c}
-Q_{3} \\
Q_{4}
\end{array}\right\}} \\
S_{4}=3.9623 \quad P_{4}=-396.2264
\end{gathered}
$$

If boundary conditions are applied in this equation $T_{4}$ is obtained as follows:

$$
\begin{gathered}
Q_{4}=525-15 T_{4} \\
525-15 T_{4}=3.9623 T_{4}-396.2264 \\
18.9623 T_{4}=921.2264 \\
T_{4}=48.582^{\circ} \mathrm{C}
\end{gathered}
$$

Other unknowns are obtained as follows: 


$$
\begin{gathered}
{\left[\begin{array}{ll}
k_{11} & k_{12} \\
k_{21} & k_{22}
\end{array}\right]\left\{\begin{array}{l}
T_{3} \\
T_{4}
\end{array}\right\}=\left\{\begin{array}{c}
-Q_{3} \\
Q_{4}
\end{array}\right\}} \\
Q_{4}=S_{4} T_{4}+P_{4} \\
k_{21} T_{3}+k_{22} T_{4}=S_{4} T_{4}+P_{4} \\
T_{3}=k_{21}^{-1}\left(-k_{22} T_{4}+S_{4} T_{4}+P_{4}\right) \\
T_{3}=\frac{-(-28 * 48.582+3.9623 * 48.582-396.2264)}{28}=55.86^{\circ} \mathrm{C} \\
{\left[\begin{array}{l}
k_{11} \\
k_{21} \\
k_{22}
\end{array}\right]\left\{\begin{array}{l}
T_{2} \\
T_{3}
\end{array}\right\}=\left\{\begin{array}{c}
-Q_{2} \\
Q_{3}
\end{array}\right\}} \\
Q_{3}=S_{3} T_{3}+P_{3} \\
k_{21} T_{2}+k_{22} T_{3}=S_{3} T_{3}+P_{3} \\
T_{2}=\frac{-(-8.5714 * 55.86+4.6154 * 55.86-461.385)}{8.5714}=79.61^{\circ} \mathrm{C}
\end{gathered}
$$

\subsection{SIMULATION RESULTS}

Heat transfer analyses of composite wall were conducted with the finite element modeling software Abaqus CAE/2014 [30]. Two-dimensional model was analyzed to obtain the temperature distributions (Figure 4). 4-node linear heat transfer quadrilateral elements with a specified element size of $5 \times 5 \mathrm{~mm}$ was used to mesh the model and for solid section, a three dimensional deformable homogeneous was used. The initial temperature $\left(100^{\circ} \mathrm{C}\right)$ was applied on the left surface of model and Film coefficient, $\beta_{R}=15 \mathrm{~W} /\left(\mathrm{m}^{2} .{ }^{0} \mathrm{~K}\right)$ was applied on the right surface where the heat transfer occurs. The distribution of temperature in the composite wall was shown in Figure 5. 
DOI:10.34186/klujes.564004

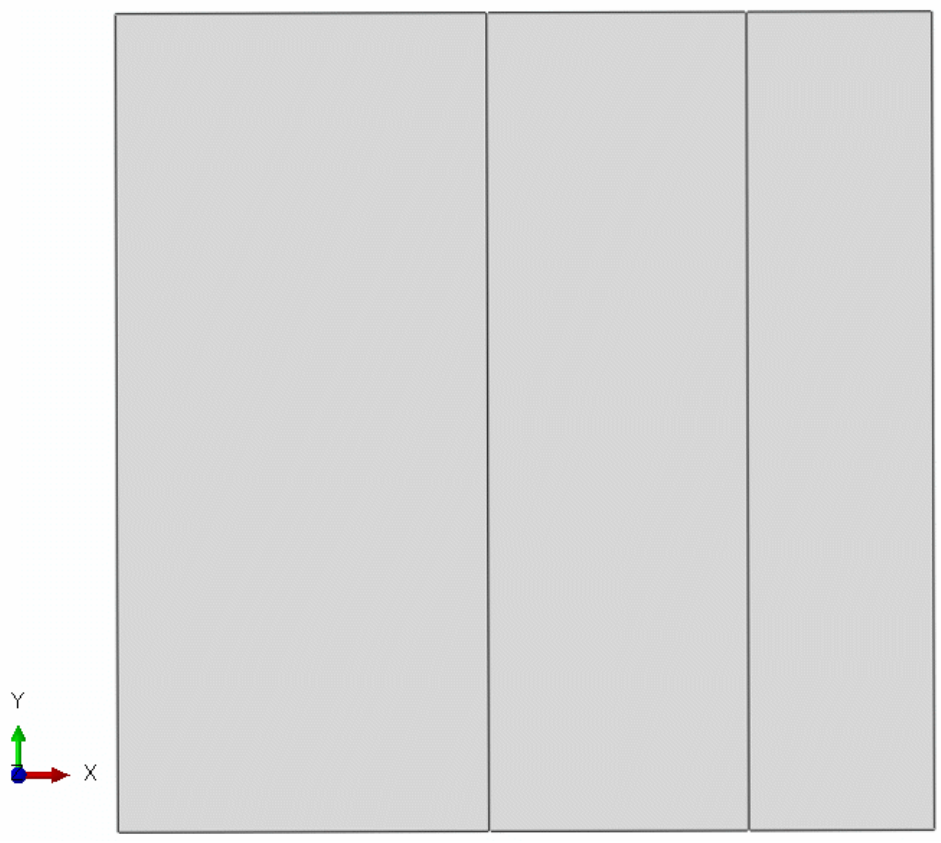

Figure 4. Two-dimensional model
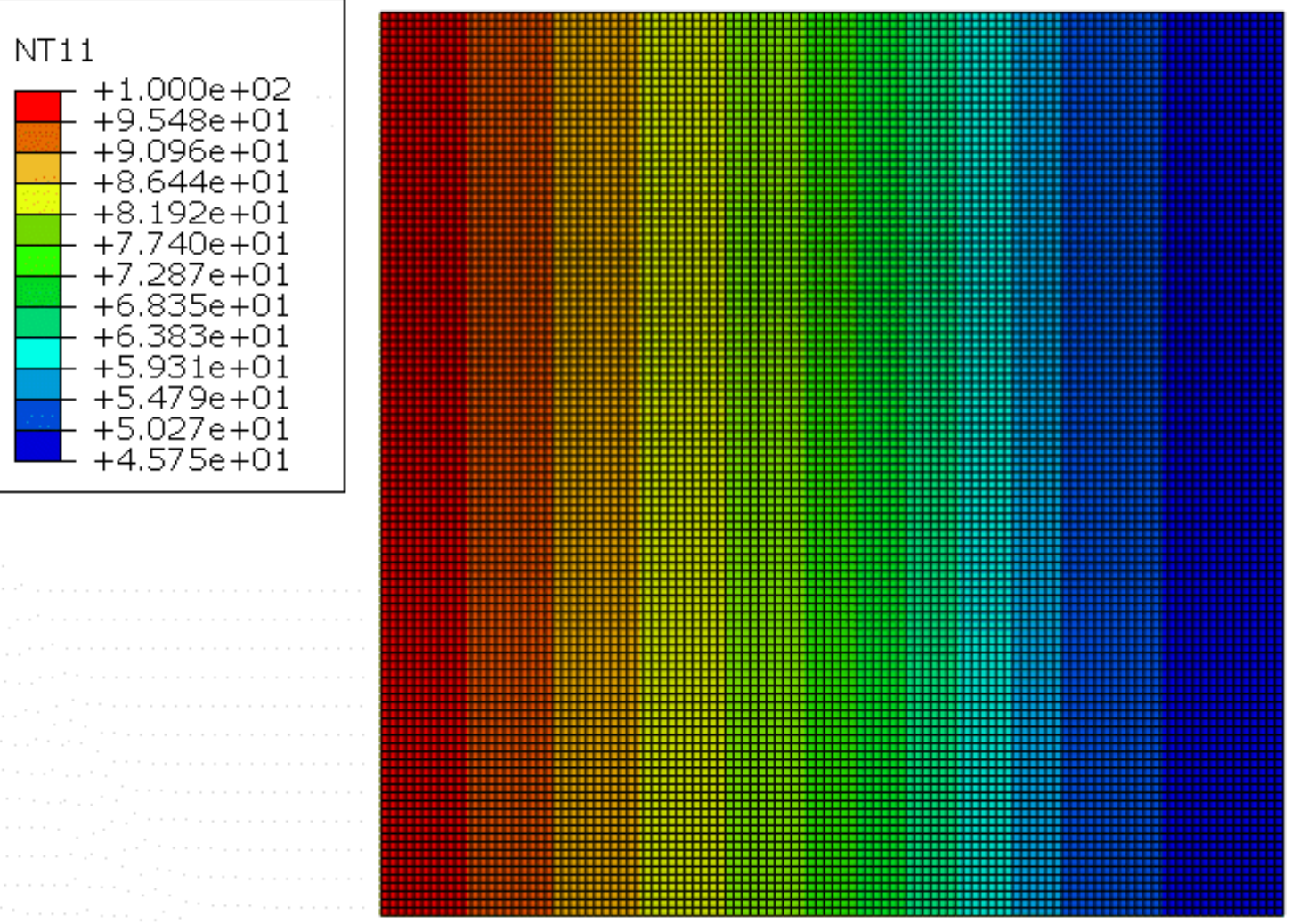

Figure 5. Distribution of temperature in the composite wall 
The results obtained from three methods were given in Table 1. The results of the simulation are in good agreement with the transfer matrix method and the modified finite element -transfer matrix method.

Table 1. Results obtained from three methods $\left(\mathrm{C}^{0}\right)$

\begin{tabular}{cccc}
\hline & TMM & MFETM & Abaqus \\
\hline $\mathrm{T}_{2}$ & 79.63 & 79.61 & 78.50 \\
\hline $\mathrm{T}_{3}$ & 55.86 & 55.86 & 53.42 \\
\hline $\mathrm{T}_{4}$ & 48.58 & 48.58 & 45.74 \\
\hline
\end{tabular}

\section{CONCLUSION}

TMM is an effective method which is used in mechanics and provides a great advantage especially in solving some mechanical problems. In this study, various versions of the TMM are briefly introduced. At the end of the work, the MFETM was applied to the heat transfer problem. As a result, because of the reduced matrix size, the Transfer Matrix Method and especially the MFETM are less time consuming than the conventional Finite Element method. The results of the simulation (Abaqus) are in good agreement with the transfer matrix method and the modified finite element -transfer matrix method. The method presented in this study was applied on a heat transfer in composite wall problem. MFETM can be easily applied to other heat transfer problems.

\section{REFERENCES}

[1] Holzer, H. Analysis of Torsional Vibration, Springer, Berlin, 1921.

[2] Myklestad, N.O. New Method of Calculating Natural Modes of Coupled Bending-Torsion Vibration of Beams. Trans. ASME., 61-67.

[3] Thompson, W. T. Matrix Solution for the Vibration of Non-Uniform Beams. J. App. Mech. 17(1950), 337-339.

[4] Thompson, W. T. Transmission of Elastic Waves Through a Stratified Solid Media, J. Appl. Phys. 21(1950), 89-93

[5] Haskel, N.A. The Dispersion of Surface Waves on Multilayered Media. Bull. seism. Soc. Am. 43 (1953), 17-34. 
[6] Pestel, E.C., Leckie, F. A. Matrix Methods in Elastomechanics. New York: McGraw-Hill, 1963.

[7] İnan, M. The Method of Initial Values and the Carry-over Matrix in Elastomechanics, Middle East Technical University, 1968.

[8] Hoerner, G.C. The Riccati Transfer Matrix Method. Ph.D. Thesis, University of Virginia, Charlottesvile, VA., 1975.

[9] Dokanish, M.A. A New Approach for Plate Vibration: Combination of Transfer Matrix and Finite Element Technique. Trans. ASME J. Eng. Ind. 94(1972), 526-530.

[10] Mcdaniel, T. J., Eversole, K. B. A Combined Finite Element-Transfer Matrix Structural Analysis Method.J. Sound Vibr. 51(1977), 157-169.

[11] Ghiatti, G., Sestieri, A. Analysis of Static and Dynamic Structural Problems by a Combined Finite Element-Transfer Matrix Method. J. Sound Vibr. 67 (1979), 35-42.

[12] Ohga, M., Shigematsu, T., Hara, T. (1984) A Combined Finite Element-Transfer Matrix Method. J. Engng Mech.Div., Am. Sot. Ciu. Engrs 110 (1984), 1335-1349.

[13] Degen, E.E., Shepbhard, M.S., Loewy, R.G. Combined Finite Element-Transfer Matrix Method Based on a Finite Mixed Formulation. Comput. Struct., 20(1985), 173-180.

[14] Chen, Y. H., Xue, H. Y. Dynamic Large Deflection Analysis of Structures by a Combined Finite Element Riccati Transfer Matrix Method on a Microcomputer. Compt. Struct. 39 (1991), No 6., 699-703.

[15] Xue, H.Y. A Combined Dynamic Finite Element-Ricatti Transfer Matrix Method for Solving Non-Linear Eigenproblems of Vibrations. Comp. Struct., 53 (1994), No.6, 1257-1261.

[16] Yuhua, C. Large Deflection Analysis of Structures by an Improved Combined Finite Element-Transfer Matrix Method. Comput Struct 55 (1995), 167-171.

[17] Bhutani, N., Loewy, R.G. Combined Finite Element-Transfer Matrix Method. J. Sound Vib., 226 (1999), No.5,1048-1052.

[18] Alimonti, L.,Atalla,N.,Sgard,F. Assessment of a hybrid finite element-transfer matrix model for flat structures with homogeneous acoustic treatments. J Acoust Soc Am. 135 (2014), No.5, 2694-2705.

[19] Fan, S., Barber, J.R. Solution of Periodic Heating Problems by the Transfer Matrix Method.Heat and Mass Trans. 45 (2002),1155-1158. 
[20] Choi, M.S. Free Vibration Analysis of Plate Structures Using Finite Element Transfer Stiffness Coefficient Method. J. Mech. Sci. Tech., 17 (2003), No. (6), 805-815.

[21] RUI, X., WANG, G., LU, Y. Transfer Matrix Method for Linear Multibody System. Multibody Syst. Dyn. 19 (2008), No.3, 179-207.

[22] Rong, B., Rui, X.T., Wang, G.P. Modified Finite Element Transfer Matrix Method for Eigenvalue Problem of Flexible Structures. J. Appl. Mech., ASCE, 78 (2011), No.2, 021016.

[23] He, B., Rui, X., Zhang, H. Transfer Matrix Method for Natural Vibration Analysis of Tree System. Math. Prob. Eng, Article ID 393204, 19 pages, 2012.

[24] Öztürk, D., Bozdogan, K., Nuhoglu, A. Modified Finite Element-Transfer Matrix Method for The Static Analysis of Structures. Struct. Eng. Mech., 43 (2012), No.6, 761-769.

[25] Öztürk, D., Bozdogan, K. B. A Method for Determination of the Fundamental Period of Layered Soil Profiles. J Appl.Comp.Mech. 3 (2017), No.4, 267-273.

[26] Demirkan, E.,Artan R.Buckling Analysis of Nanobeams Based on Nonlocal Timoshenko Beam Model by the Method of Initial Values, Int J Struct Stab Dy, 19 (2019), No. 3, 17 p.

[27] Xu, P., Jiang, G. Calculation of Natural Frequencies of Retaining Walls Using the Transfer Matrix Method. Adv. Civ Eng.(2019), Article ID 2156475, 8 pages.

[28] Kang, S., Nanfang, J., Han, K., Shen, X., Wang, W. Theoretical modelling of periodic graphene structures. Physica B Condens Matter. 563 (2019), No.15, 36-40.

[29] Reddy, J.N. An Introduction to The Finite Element Method, 3, McGraw-Hill, New York, 2005.

[30] Abaqus, Dassault Systemes Simulia Corp, Providence (2014) 